\title{
Öğretmenlik Mesleği ve Yaşam Boyu Öğrenme: Öğretmen Adayları Penceresinden
}

\section{Teaching Profession and Lifelong Learning: From the Perspective of Teacher Candidates}

\begin{abstract}
Kerim ÜNAL*, Cenk AKAY**
Öz: Eğitim programı, yöneticiler, eğitim uzmanları, eğitim teknolojisi, fiziki olanaklar, finans kaynakları, öğrenci ve öğretmen, eğitim sistemini oluşturan öğelerdir ve eğitim programının uygulayıcısı olan öğretmenler, önemli bir öğedir. Bundan dolayı, günümüz öğretmenlerinin özverili çalışabilmeleri için öğretmenlik mesleğine yönelik olumlu bir tutuma sahip olmaları ve güncel gelişmeleri takip edebilecekleri, değişimlere uyum sağlayabilecekleri ve kendilerini sürekli geliştirebilecekleri, ayrıca bu değişimleri sınıfa yansıtabilecekleri yaşam boyu öğrenme becerilerine sahip olmaları büyük önem taşımaktadır. $\mathrm{Bu}$ çalışmada, pedagojik formasyon eğitimi alan öğretmen adaylarının öğretmenlik mesleğine yönelik tutumlarını ve yaşam boyu öğrenmeye ilişkin eğilimleri çeşitli değişkenlere göre belirlenmiş ve öğretmenlik mesleğine yönelik tutumları ile yaşam boyu öğrenmeye ilişkin eğilimleri arasında herhangi bir ilişkisinin olup olmadığı incelenmiştir. Öğretmen adaylarının öğretmenlik mesleğine yönelik olumlu tutum içinde oldukları saptanmıştır. Öğretmen adaylarının yaşam boyu öğrenme eğilimlerine bakıldığında, yaşam boyu öğrenme eğilimlerinin yüksek olduğu belirlenmiştir. Öğretmen adaylarının "yaşam boyu öğrenme eğilimleri” ile "öğretmenlik mesleğine yönelik tutumları" arasında, doğru (pozitif) yönlü orta düzeyde bir ilişkinin olduğu bulunmuştur. Ayrıca, öğretmen adaylarının açık uçlu sorulara verdikleri cevaplardan öğretmenliği nasıl gördükleri üç tema altında, yaşam boyu öğrenmeyi nasıl gördükleri de iki tema altında toplanmıştır.
\end{abstract}

Anahtar Kelimeler: Pedagojik formasyon, öğretmenlik mesleği, yaşam boyu öğrenme

\begin{abstract}
Curriculum, administrators, educationists, education technologies, physical facilities, financial sources, students and teachers constitute the education systems and the teachers are important ones. For this reason, in order to be able to work devotedly and attentively, it is mandatory that today's teachers have positive attitude towards teaching profession and have high lifelong learning tendencies. In this study, the attitudes towards teaching profession and the lifelong learning tendencies of the teacher candidates attending to pedagogical formation certificate program were outlined according to various variables and whether there was any relationship between the attitudes towards teaching profession and the lifelong learning tendencies was investigated. It can be found that the teacher candidates had positive attitudes towards the teaching profession. Moreover, teacher candidates' lifelong learning tendencies were said to be high. It can also be underlined that there was a positive medium-level relationship between the attitudes towards teaching profession and lifelong learning tendencies of the teacher candidates. Besides, the responses to how they saw the teaching profession were grouped under three themes and those to how they perceived lifelong learning under two themes.
\end{abstract}

Keywords: Pedagogical formation, teaching profession, lifelong learning

\section{Giriş}

Türkiye'de ve dünyada, eğitim sistemleri her geçen gün gelişmekte, inovatif ve vizyoner bakış açısı ile değişimlere uğramaktadır. Bu değişim ve gelişim sürecinin en önemli unsurlarından birisi de öğretmendir. Öğretmenlik mesleği sadece öğrenme-öğretme sürecinin uygulanmasını değil aynı zamanda toplumsal değişimin ve gelişimin de önderliğini yapmayı ve bu süreci kolaylaştırmayı hedefleyen bir meslektir.

Öğretmenlik; 1739 Sayılı Milli Eğitim Temel Kanununda (Milli Eğitim Bakanlığı (MEB), 1973), devletin eğitim, öğretim ve bununla ilgili yönetim görevlerini üzerine alan özel bir uzmanlık mesleği olarak tanımlanmakta ve öğretmenlerin bu görevlerini Türk Millî

*Okt. Dr., Mersin Üniversitesi Eğitim Fakültesi, Mersin-Türkiye, e-posta: kerimunal@ mersin.edu.tr

**Yrd. Doç. Dr., Mersin Üniversitesi Eğitim Fakültesi, Mersin-Türkiye, e-posta: cenkakay35@ hotmail.com 
Eğitiminin amaçlarına ve temel ilkelerine uygun olarak yerine getirmekle yükümlü oldukları belirtilmektedir. Öğretmenlik, eğitim örgütlerindeki bir konumu ve o konumun öngördüğü davranışlar setini oluşturan, konumun statü, görev ve ilişkilerini ifade eden bir kavramdır (Üstüner, 2006). Her meslekte olduğu gibi öğretmenliğin de başarıyla uygulanması mesleğe karş1 duyulan tutumlardan etkilenmektedir. Öğretmenlik mesleğinin ne denli zor ve sorumluluk gerektiren bir meslek olduğu tüm çevrelerce kabul edilmektedir. Öğretmen davranışlarını belirleyen temel etkenlerden birisi de, öğretmenlik mesleğini yapan bir kişinin bu mesleğe karş1 tutumunun niteliğidir (Üstüner, 2006). Öğretmenlik mesleği ile ilgili sorunlar düşünüldüğünde, öğretmenlerin kendilerinden beklenen rolleri yerine getirmelerini etkileyen önemli bir değişkenin, öğretmenliği sevme, saygı duyma ve benimseme özelliklerini kapsayan tutumlar olduğu düşünülmektedir (Pehlivan, 2008). Ayrıca, bireyin öğretmenlik mesleğine olan yatkınlığı ve mesleği isteyerek seçip seçmediği gibi faktörlerin mesleki başarıyı etkileyen unsurlar olduğu bilinmektedir (Oktay, 1991). Öğretmenlik mesleğine yönelik tutumlar da bu yüzden çok sayıda çalışmaya araştırma konusu olmuştur (Çapri ve Çelikkaleli, 2008; Demirtaş, Cömert ve Özer, 2011; Eraslan ve Çakı1c1, 2011; Erdem, Gezer ve Çokadar, 2005; Ocak ve Demirdelen, 2008; Şimşek, 2005).

Öğretmenlikte tutumun yanı sıra mesleki başarıyı etkileyen bir diğer unsur da öğretmenin sahip olması gereken nitelik ve yeterliklerdir. Şişman (2009), öğretmenlik mesleğini benimseyen, bu mesleğin bir üyesi olmaktan gurur duyan, mesleki etiğe değer veren öğretmenlerin mesleğin gerektirdiği temel nitelikleri taşıdıklarını ancak, mesleğe yönelik olumsuz algilara sahip bireylerin bu niteliklerden yoksun kalabileceğini ifade etmektedir. Belirtilen nitelikler MEB tarafından düzenlenmiş ve 11.07.2012 tarihinde MEB web sayfasında yayınlanmıştır ve sürekli güncellenmektedir (MEB, 2016).

MEB'in (2016) hazırladığı Öğretmenlik Mesleği Yeterlikleri kitapçı̆̆ı tanıtımında; öğretmen yeterliklerinin, Millî Eğitim hedeflerinin desteklenmesine katkı sağlamak amacıyla; öğretmenlik mesleğinin statüsü ve kalitesi açısından toplumsal beklentilerde tutarlılık oluşturmak, öğretmenlerin bilgi, beceri, tutum ve değerlerini tanımlamak, toplum tarafindan fark edilmesini ve toplumun gözünde statülerinin yükseltilmesini sağlamak ve toplum için kalite güvencesini oluşturmak gibi pek çok amacın gerçekleştirilmesi için hazırlandığı yazılmıştır.

MEB Öğretmenlik Mesleği Genel Yeterliklerini 6 yeterlik alanı, 31 alt yeterlik ve 233 performans göstergesinden oluşturmaktadır. Bu yeterlik alanları;

a) Kişisel ve Mesleki Değerler-Mesleki Gelişim

b) Öğrenciyi Tanıma

c) Öğrenme ve Öğretme Süreci

d) Öğrenmeyi, Gelişimi İzleme ve Değerlendirme

e) Okul-Aile ve Toplum İlișkileri

f) Program ve İçerik Bilgisi'dir.

Öğretmenlerin ve öğretmen adaylarının hem öğretmenlik mesleğine yönelik olumlu tutum sergileyebilmeleri hem de MEB'in sunmuş olduğu yeterliklere sahip olabilmeleri sadece öğretmenlik eğitim süreci ile mümkün gözükmemektedir. Özellikle öğrenme-öğretme süreci, izleme-değerlendirme ve ögretim teknolojilerindeki yenilikler, program geliştirme çalışmaları ile kişisel gelişim faaliyetleri öğretmenlerin ve öğretmen adaylarının mesleklerini başarıyla yapabilmeleri için yaşam boyu öğrenme becerilerini etkin olarak işe koşmaları gerekliliğini ortaya koymaktadir.

Yaşam boyu öğrenme, her bireyin değişimlere ayak uydurmaya, bireysel gelişim açısından gerek mesleki gerek genel alanda daha ileri düzeyde eğitim fırsatlarından yararlanmaya duyduğu ihtiyaç kapsamında amaçlı ve rastlantı ürünü öğrenme yaşantılarını kapsamaktadır (Kurt, 2000). Özellikle öğretmenlerin mesleki gelişimleri için sahip olmaları beklenen yaşam boyu öğrenme becerilerinin mesleğe yönelik olumlu tutum geliştirebilmelerinde önemli rol oynayacağı düşünülebilir. Ülkemizde öğretmen yetiştirme her ne kadar 1980'li yıllardan sonra üniversiteler kapsamındaki dört yıllık eğitim fakülteleri aracılığıyla yürütülse de belli fakültelerden mezun olan öğrenciler de, pedagojik formasyon programını başarı ile tamamlamaları şartı ile öğretmenlik mesleğine atanabilmektedirler. 
Yüksek Öğretim Kurumu (YÖK)'nun (2014) 20 Şubat 2014 tarihli Pedagojik Formasyon Eğitimi Sertifika Programına İlişkin Usul ve Esaslara göre, Üniversitelerin kurumsal kapasitesine bağlı olarak en erken lisans programlarının birinci sınıfını (ikinci yarı yılını) tamamlamış öğrenciler, program açma izni verilen ilgili üniversitelerin eğitim/eğitim bilimleri fakültesi ve eğitim bilimleri bölümünde açllan pedagojik formasyon eğitimi sertifika programına başvurabilmektedirler. Bu bireyler yaşam boyu öğrenme kapsamında lisans eğitimlerinin yanı sıra farklı bir alanda öğrenme yaşantıları kazanmaya çalışmakta diğer bir deyişle yaşam boyu öğrenme becerilerini işe koşmaktadırlar.

Alan yazın incelendiğinde öğretmenlik mesleğine yönelik öğretmen adaylarının tutumlarını inceleyen çok sayıda araştırmaya rastlanıldığ yukarıda sunulmuştu. Ancak öğretmen adaylarının hem tutumlarını hem de yaşam boyu öğrenme becerilerini inceleyen, her ikisinin arasındaki ilişkiyi ortaya koymaya çalışan araştırma (örnek Çam ve Üstün, 2016) sayısının az olduğu görülmektedir. Ayrıca mesleğe yönelik tutumları etkileyebilecek unsurların günümüzde değişebileceği, yaşam boyu öğrenmeye ilişkin eğilimlerinin bu değişimlerden etkilenebileceği doğurgularından yola çıkarak bu araştırmanın yapılmasına karar verilmiştir.

$\mathrm{Bu}$ çalışmanın amacı, pedagojik formasyon eğitimi alan öğretmen adaylarının öğretmenlik mesleğine yönelik tutumlarını ve yaşam boyu öğrenmeye ilişkin eğilimlerini çeşitli değişkenlere göre belirlemek ve öğretmenlik mesleğine yönelik tutum ile yaşam boyu öğrenmeye ilişkin eğilimler arasında herhangi bir ilişkisinin olup olmadığını ortaya koymaktır. Araştırmanın alt amaçları aşağıda sunulmuştur;

1) Öğretmen adaylarının "öğretmenlik mesleğine yönelik tutumları" cinsiyet, yaş ve bölüm değişkenlerine göre anlamlı bir farklılık göstermekte midir?

2) Öğretmen adaylarının "yaşam boyu öğrenme eğilimleri” cinsiyet, yaş ve bölüm değişkenlerine göre anlamlı bir farklılık göstermekte midir?

3) Öğretmen adaylarının "yaşam boyu öğrenme eğilimleri” ile "öğretmenlik mesleğine yönelik tutumları" arasında anlamlı bir ilişki var mıdır?

4) Öğretmen adaylarının "öğretmenlik mesleği" ve "yaşam boyu öğrenme" hakkında görüşleri nelerdir?

\section{Yöntem}

\section{Araştırma Deseni}

$\mathrm{Bu}$ çalışmanın amacı, pedagojik formasyon eğitimi alan öğretmen adaylarının öğretmenlik mesleğine yönelik tutumlarını ve yaşam boyu öğrenmeye ilişkin eğilimlerini çeşitli değişkenlere göre belirlemek ve öğretmenlik mesleğine yönelik tutum ile yaşam boyu öğrenmeye ilişkin eğilimler arasında herhangi bir ilişkisinin olup olmadığını ortaya koymaktır. Bundan dolayı, bu araştırmanın amacına uygun olarak ilişkisel tarama modeli kullanılmıştır. İlişkisel tarama modeli, iki ya da daha fazla değişken arasında ilişki olup olmadığı belirlemeye yönelik kullanılan bir araştırma desenidir (Karasar, 2010; Erkuş, 2011).

\section{Çalışma Grubu}

Araştırma grubunu, bir devlet üniversitesi eğitim fakültesi'nde 2013-2014 eğitim öğretim Bahar yarı yılı Ocak ayında açılan pedagojik formasyon sertifika programına katılan 232 öğretmen adayı oluşturmaktadır. Araştırmaya dâhil olan öğretmen adaylarının 144'ü kadın (\% 62.1), 88'i (\%37.9) erkektir. Öğretmen adaylarının 6's1 (\%2.6) 20-22; 149'u (\%64.2) 23-25; 53'ü (\%22.8) 26-28; 17'si (\%7.3) 29-31 ve 7'si (\%3) 32-34 yaş arasında oldukları belirlenmiş̦tir. Ayrıca, öğretmen adaylarının 221'i (\%95.3) fen-edebiyat fakültesi (Türk Dili ve Edebiyatı bölümü $(\mathrm{n}=58)$, Biyoloji bölümü $(\mathrm{n}=31)$, Felsefe bölümü $(\mathrm{n}=11)$, Fizik bölümü $(\mathrm{n}=15)$, İngiliz Dili ve Edebiyatı bölümü $(n=29)$, Kimya bölümü $(n=26)$, Sosyoloji bölümü $(n=5)$ ve Tarih bölümü $(\mathrm{n}=46))$ mezunu iken 11'i (\%4.7) ise takı teknolojileri ve tasarımı yüksekokulu mezunudur. 


\section{Veri Toplama Araçları}

Araştırmada kişisel bilgiler formu, "Öğretmenlik Mesleğine Yönelik Tutum Ölçeği (ÖMYTÖ)" "Yaşam Boyu Öğrenme Eğilimleri Ölçeği (YBÖEÖ)" ve iki açık uçlu soru kullanılmıştır. Kişisel bilgiler formunda, öğretmen adaylarından cinsiyet, yaş, mezun oldukları lise, mezun oldukları fakülte ve bölüm ile ilgili bilgi elde etmek amaçlanmıştır.

Üstüner (2006) tarafından geliştirilen ÖMYTÖ, 24 olumlu ve 10 olumsuz maddeden oluşmaktadır. 5'li Likert tipinde hazırlanan bu ölçekte, puanlama; 5 "Tamamen Katılıyorum", 4 "Çoğunlukla Katılıyorum", 3 "Orta Düzeyde Katılıyorum", 2 "Kısmen Katıllyorum", 1 "Hiç Katılmıyorum" şeklinde düzenlenmiştir. Madde test korelasyon değerlerinin 0.74 ile 0.42 arasında değişkenlik gösterdiği belirlenen bu ölçeğin, ölçüt ölçek geçerliliği 0.89 , iç tutarlılık katsayısı (Cronbah Alpha) 0.93 olarak bulunmuştur. $\mathrm{Bu}$ araştırmada yapılan güvenirlik analizinde ise ölçeğin güvenirliği 0.89 olarak bulunmuştur. ÖMYTÖ'den alınabilecek en düşük puan 34 , en yüksek puan ise 170 'dir.

Coşkun Diker (2009) tarafından geliştirilen YBÖEÖ, 27 maddeden oluşmaktadır. Ölçeğin, motivasyon (6 madde), sebat (6 madde), öğrenmeyi düzenlemede yoksunluk (6 madde) ve merak yoksunluğu (9 madde) olarak tanımlanmış 4 boyutu vardır. Ölçeğin iç tutarlılık katsayısı (Cronbah Alpha) 0.89 olarak bulunmuştur. Bu araştırmada yapılan güvenirlik analizinde ise ölçeğin güvenirliği 0.85 olarak hesaplanmıştır. Altılı likert tipinde hazırlanan bu ölçekte puanlama; 6 "çok uyuyor", 5 "kısmen uyuyor", 4 "çok az uyuyor", 3 "çok az uymuyor", 2 "kısmen uymuyor", ve 1 "hiç uymuyor" şeklinde düzenlenmiştir. Ölçekten alınabilecek en düşük puan 27 ve en yüksek puan 162'dir. Ölçeğin orta noktasının 3,5 ve ölçek ortanca puanının ise 94,5 olarak belirlenmiştir (Coşkun Diker ve Demirel, 2012)

Son olarak, veri toplamak için hazırlanan ölçme aracına iki açık uçlu soru eklenmiştir. Bunlardan birincisi, "Öğretmenlik sizin için ne ifade ediyor?", ikincisi de "Yaşam boyu öğrenme sizin için ne ifade ediyor?" sorusudur. Bu sorularla, öğretmen adaylarının öğretmenlik mesleği ve yaşam boyu öğrenme hakkında ne düşündüklerini ortaya koymak amaçlanmıştır.

\section{Verilerin Toplanması ve Analizi}

Bir devlet üniversitesi eğitim fakültesinde verilen pedagojik formasyon eğitimine katılan 265 öğretmen adayına pedagojik formasyon eğitimin başlamasından iki ay sonra (Mart 2014) ölçme araçları uygulanmıştır. Öğretmen adaylarından sekiz tanesi ölçme aracını boş verdikleri ve 10 tanesi ise ölçme araçlarını eksik doldurdukları için 18 veri değerlendirme dışı bırakılmıştır. Sonrasında, her iki ölçekte yer alan olumsuz maddeler de tersten kodlama işlemi gerçekleştirilmiştir. Yapılan frekans ve yüzde analizleri sonucunda, veri setinde kayıp veriler bulunmuş ve bu kayıp veriler için genel ortalama alınmıştır. Uç değer analizi sonrasında toplam 15 veri uç değer göstermiş ve değerlendirme dışı bırakılmıştır. Sonuç olarak, analizler 232 öğretmen adayından elde edilen verilerle yapılmıştır.

Her bir ölçekten toplanan veriler, öncelikle cinsiyet, yaş ve bölüm değişkenlerine göre değerlendirilmiştir. Cinsiyet değişkenine göre analizlerde bağımsız örneklemler t-testi, diğer değişkenler için ise tek yönlü varyans analizi yapılmıştır. ÖMYTÖ ile YBÖEÖ arasında anlamlı bir ilişkinin olup olmadığını belirlemek için ise iki değişkenli korelasyon (Pearson) katsayısına bakılmıştır. Analizler için IBM SPSS 20 paket programı kullanılmıştır.

Açık uçlu soruların değerlendirilmesi için ise içerik analizi yapılmıştır. Öğretmen adaylarının vermiş oldukları cevapları iki araştırmacı bağımsız olarak temalarına ayırmış ve daha sonra bu temalar karşılaştırılmıştır. Karşılaştırma sonucu, Miles Huberman formülü (Görüş Birliği/ Görüş Birliği+ Görüş Ayrılığı) kullanılarak güvenirlik hesaplanmıştır. Hesaplama sonucunda, öğretmenlik mesleğine yönelik görüşleri için güvenirlik katsayısı 85/90 = 0.94 ve yaşam boyu öğrenmeye ilişkin görüşleri için ise güvenirlik katsayıs1 78/81=0.96 olarak bulunmuştur.

\section{Bulgular}

Her bir ölçekten toplanan veriler ayrı ayrı, cinsiyet, yaş ve bölüm değişkenlerine göre değerlendirilmiş ve "yaşam boyu öğrenme eğilimi" ile "öğretmenlik mesleğine yönelik tutum" 
arasındaki ilişkiye bakılmıştır. Ayrıca, öğretmen adaylarının öğretmenlik mesleği ve yaşam boyu öğrenme hakkında ne düşündükleri belirlenmiştir.

\section{Öğretmenlik Mesleğine Yönelik Tutum}

Formasyon eğitimine katılan öğretmen adaylarının öğretmenlik mesleğine yönelik tutumları incelendiğinde (Tablo 1), ölçekten alınan en düşük puanın 77, en yüksek puanın ise 170 olduğu görülmektedir. 232 öğretmen adayının ölçekten aldığı puanlar ortalaması ise $\bar{X}=123.50$ 'dir.

Tablo 1

Öğretmenlik Mesleğine Yönelik Genel Tutum

\begin{tabular}{cccccc}
\hline $\mathrm{n}$ & $\overline{\mathrm{X}}$ & $\mathrm{SS}$ & En düşük puan & En yüksek puan & $\overline{\mathrm{X}} /$ Ölçek Madde Sayısı (34) \\
\hline 232 & 123.50 & 20.22 & 77 & 170 & 3,63 \\
\hline
\end{tabular}

Ölçekten alınan puanlar ortalamasının madde sayısına bölündüğünde, ölçekten alınan puanlar ortalaması da 3,63 olarak bulunmuştur. Bu sonuç, pedagojik formasyon eğitimine katılan öğretmen adaylarının, öğretmenlik mesleğine yönelik tutumlarında pozitif yönde bir eğilime sahip oldukları söylenebilir.

Cinsiyet: Öğretmen adaylarının “öğretmenlik mesleğine yönelik tutumları"'nın, cinsiyete göre farklılık gösterip göstermediği incelenmiş ve elde edilen sonuçlar Tablo 2'de verilmiştir.

Tablo 2

Cinsiyet Değişkenine Göre Öğretmenlik Mesleğine Yönelik Tutum

\begin{tabular}{lllllll}
\hline CINSIYYT & $\mathrm{n}$ & $\overline{\mathrm{X}}$ & $\mathrm{ss}$ & $\mathrm{t}$ & $\mathrm{s} . \mathrm{d}$ & $\mathrm{p}$ \\
\hline Kadın & 144 & 3.80 & 0.60 & 0.350 & 230 & 0.727 \\
Erkek & 88 & 3.77 & 0.56 & & & \\
\hline
\end{tabular}

Öğretmen adaylarının “öğretmenlik mesleğine yönelik tutumları”"nın, cinsiyete göre farklılık gösterip göstermediğine bakıldığında (Tablo 2), kadın öğretmen adaylarının ÖMYT puan ortalaması $\overline{\mathrm{X}}=3.80$ (ss=0.60) iken erkek öğretmen adaylarının ÖMYT puan ortalaması $\bar{X}=3.77$ (ss=0.56) olduğu görülmektedir. Bir başka ifadeyle, pedagojik formasyon eğitimine katılan hem kadın hem de erkek öğretmen adaylarının, öğretmenlik mesleğine yönelik tutumlarında pozitif yönde bir eğilime sahip olduğu bulunmuştur. Ancak, yapılan bağımsız örneklemler t-testi sonucu öğretmen adaylarının öğretmenlik mesleğine yönelik tutumlarında cinsiyete göre anlamlı bir farkın olmadığını ortaya koymuştur $\left(\mathrm{t}_{230}=.350 ; \mathrm{p}>.05\right)$.

Yaş: Öğretmen adaylarının “öğretmenlik mesleğine yönelik tutumları”"nın, yaş değişkenine göre farklılık gösterip göstermediği incelenmiş ve elde edilen sonuçlar Tablo 3'de verilmiştir.

Tablo 3

Yaş Değişkenine Göre Öğretmenlik Mesleğine Yönelik Tutum

\begin{tabular}{llllll}
\hline YAS & $\mathrm{n}$ & $\overline{\mathrm{X}}$ & $\mathrm{ss}$ & $\mathrm{F}$ & $\mathrm{p}$ \\
\hline $20-22$ & 6 & 3.63 & 0.53 & & \\
$23-25$ & 149 & 3.78 & 0.59 & .197 & .940 \\
$26-28$ & 53 & 3.78 & 0.60 & & \\
$29-31$ & 17 & 3.85 & 0.62 & & \\
$32-34$ & 7 & 3.89 & 0.63 & & \\
\hline
\end{tabular}

Öğretmen adaylarının öğretmenlik mesleğine yönelik tutum puanlarının yaşa göre dağılımı incelendiğinde, ÖMYT ortalama puanlarının $\bar{X}=3.63$ ile $\bar{X}=3.89$ arasında değiştiği ve ögretmen adaylarının, öğretmenlik mesleğine yönelik tutumlarında pozitif yönde bir eğilime sahip olduğu belirlenmiştir. Ayrıca, öğretmen adaylarının ÖMYT puanlarının yaş değişkeniyle 
doğru orantılı olduğu söylenebilir. Bir başka ifadeyle, öğretmen adaylarının yaşları arttıkça, öğretmenlik mesleğine yönelik tutumlarında da pozitif yönde bir yükselmenin olduğu söylenebilir. Ancak, puan ortalamalarında bir yükselme gözlenmesine rağmen, öğretmen adaylarının ÖMYT puanlarının yaşa göre dağılımında gruplar arası anlamlı bir farkın olmadığı bulunmuştur $(\mathrm{F}=.197 ; \mathrm{p}>.05)$.

Bölüm: Öğretmen adaylarının öğretmenlik mesleğine yönelik tutum puanlarının mezun oldukları fakülte türüne göre dağılımına bakıldığında, araştırmaya katılan bütün öğretmen adaylarının sadece iki fakülteden mezun olduğu görülmüştür. Fen Edebiyat Fakültesi mezunu öğretmen adaylarının $(n=221)$ sayısı ve Takı Teknolojileri ve Tasarımı yüksekokulu mezunu öğretmen adaylarının $(n=11)$ sayısı arasında çok fazla fark olduğu için Takı Teknolojileri ve Tasarımı Yüksekokulunu mezun olunan bir bölüm olarak değerlendirip, bölümler arası bir farklılık olup olmadığına bakılmıştır. Elde edilen sonuçlar Tablo 4'de gösterilmiştir.

Tablo 4

Bölüm Değişkenine Göre Öğretmenlik Mesleğine Yönelik Tutum

\begin{tabular}{llllll}
\hline Bölüm & $\mathrm{n}$ & $\overline{\mathrm{X}}$ & ss & $\mathrm{F}$ & $\mathrm{p}$ \\
\hline Türk Dili ve Edebiyat1 & 58 & 3.34 & 0.27 & & \\
Biyoloji & 31 & 3.80 & 0.52 & 7.939 & .000 \\
Felsefe & 11 & 4.08 & 0.60 & & \\
Fizik & 15 & 3.76 & 0.72 & & \\
İngiliz Dili ve Edebiyat1 & 29 & 4.02 & 0.64 & & \\
Kimya & 26 & 3.98 & 0.45 & & \\
Sosyoloji & 5 & 4.22 & 0.69 & & \\
Tarih & 46 & 3.90 & 0.62 & & \\
Tak1 Teknolojileri ve Tasarımı & 11 & 4.13 & 0.53 & & \\
\hline
\end{tabular}

Öğretmen adaylarının öğretmenlik mesleğine yönelik tutum puanlarının mezun oldukları bölüm türüne göre dağılımına bakıldığında (Tablo 4), ÖMYT puan ortalamalarının $\bar{X}=3.34$ ile $\bar{X}=4.22$ arasında değiștiği görülmektedir. Öğretmen adaylarının ÖMYT puanlarının mezun oldukları bölüm türüne göre dağılımında anlamlı bir farkın olup olmadığını ortaya koymak için yapılan tek yönlü varyans analizi sonucuna göre gruplar arasında anlamlı bir farkın olduğu görülmektedir ( $F=7.939 ; p<.05)$.

$\mathrm{Bu}$ farkın hangi bölümlerden kaynaklandığını görmek için yapılan LSD testi sonucunda, Türk Dili ve Edebiyatı bölümü ile Biyoloji $(\mathrm{p}=.000<.05)$, Felsefe $(\mathrm{p}=.000<.05)$, Fizik $(\mathrm{p}=.007<.05)$, İngiliz Dili ve Edebiyat $1(\mathrm{p}=.000<.05)$, Kimya $(\mathrm{p}=.000<.05)$, Sosyoloji $(\mathrm{p}=.000<.05)$, Tak1 Teknolojileri ve Tasarımı $(\mathrm{p}=.000<.05)$, ve Tarih $(\mathrm{p}=.000<.05)$, bölümleri arasında olduğu izlenmiştir.

\section{Yașam Boyu Öğrenme Ĕ̆ilimleri}

Pedagojik formasyon eğitimine katılan öğretmen adaylarının yaşam boyu öğrenme eğilimleri incelendiğinde (Tablo 5), ölçekten alınan en düşük puanın 79, en yüksek puanın ise 162 olduğu görülmektedir. 232 öğretmen adayının ölçekten aldığı puanlar ortalaması ise $\bar{X}=128.59$ 'dur. Öğretmen adaylarının YBÖE ölçeğinden aldıkları puanlar ortalaması, ölçek orta puanının (94.5) üstündedir. Buna göre, pedagojik formasyon eğitimine katılan öğretmen adaylarının, yaşam boyu öğrenme eğilimlerinin yüksek olduğu söylenebilir. 
Tablo 5

YBÖEÖ’den Elde Edilen Puanlara İlişkin Betimsel İstatistikler

\begin{tabular}{lccccc}
\hline YBÖEÖ & $n$ & $\bar{X}$ & Ss & $\begin{array}{c}\text { En } \\
\text { düşük } \\
\text { puan }\end{array}$ & $\begin{array}{c}\text { En } \\
\text { yüksek } \\
\text { puan }\end{array}$ \\
\hline Genel Puan & 232 & 128.67 & 21.07 & 79 & 162 \\
\hline 1. alt boyut: Güdülenme & 232 & 31.65 & 4.14 & 6 & 36 \\
2. alt boyut: Sebat & 232 & 29.19 & 4.83 & 6 & 36 \\
3. alt boyut: Öğrenmeyi Düzenlemede Yoksunluk & 232 & 26.73 & 7.69 & 8 & 36 \\
4. alt boyut: Merak Yoksunluğu & 232 & 41.07 & 11.11 & 9 & 54 \\
\hline
\end{tabular}

Ek olarak, yaşam boyu öğrenme ölçeği alt boyutlarına ilişkin sonuçlar incelendiğinde, ölçeğin alt boyutlarına ilişkin puan ortalamalarının sırasıyla güdülenme $(\bar{X}=31.65)$, sebat $(\bar{X}=29.19)$, öğrenmeyi düzenlemede yoksunluk $(\bar{X}=26.71)$ ve merak yoksunluğu $(\bar{X}=41.01)$ olduğu görülmektedir. Öğretmen adaylarının ölçek maddelerine verdikleri yanıtlar incelendiğinde, öğretmen adaylarının yaşam boyu öğrenme eğiliminde oldukları, yaşamlarının ilerleyen dönemlerinde öğrenmeye açık oldukları, yeni bilgi ve becerileri öğrenmeyi yaşamlarının bir parçası haline getirdikleri ve kendi öğrenmelerini düzenleyebildikleri şeklinde yorumlanabilir.

Cinsiyet: Öğretmen adaylarının yaşam boyu öğrenme eğilimlerinin, cinsiyete göre farklılık gösterip göstermediği incelenmiş ve elde edilen sonuçlar Tablo 6'da verilmiştir.

Tablo 6

Cinsiyet Değişkenine Göre Yaşam Boyu Öğrenme Eğilimleri

\begin{tabular}{lllllll}
\hline ĊNSIYYET & $\mathrm{n}$ & $\overline{\mathrm{X}}$ & $\mathrm{ss}$ & $\mathrm{t}$ & $\mathrm{s} . \mathrm{d}$. & $\mathrm{p}$ \\
\hline Kadın & 144 & 3.59 & .63 & -1.399 & 230 & .163 \\
Erkek & 88 & 3.71 & .65 & & & \\
\hline
\end{tabular}

Öğretmen adaylarının yaşam boyu öğrenme eğilimlerinde cinsiyete göre bir farklılık olup olmadığına bakıldığında, kadın öğretmen adaylarının yaşam boyu öğrenme eğilim puan ortalamaları $\bar{X}=3.59$ ( $\mathrm{ss}=0.63$ ) iken erkek öğretmen adaylarının yaşam boyu öğrenme eğilim puan ortalamalarının $\bar{X}=3.71$ (ss=.65) olduğu görülmektedir. Her iki ortalama da ölçeğin ortalamasının ( $\bar{X}=3.5)$ üstünde ve aralarında bir farkın olmadığı ve öğretmen adaylarının cinsiyete göre yaşam boyu öğrenme eğilimlerinin olumlu olduğu söylenebilir. Yapılan bağımsız örneklemler t-testi sonucu da öğretmen adaylarının yaşam boyu öğrenme eğilimlerinde cinsiyete göre manidar bir farkın olmadığını ortaya koymuştur $\left(\mathrm{t}_{230}=-1.399 ; \mathrm{p}>.05\right)$.

Yaş: Öğretmen adaylarının yaşam boyu öğrenme eğilimlerinin, yaş değişkenine göre farklılık gösterip göstermediği incelenmiş ve elde edilen sonuçlar Tablo 7'de verilmiştir.

Tablo 7

Yaş Değişkenine Göre Yaşam Boyu Öğrenme Eğilimleri

\begin{tabular}{llllll}
\hline YAS & $\mathrm{n}$ & $\overline{\mathrm{X}}$ & ss & $\mathrm{F}$ & $\mathrm{p}$ \\
\hline $20-22$ & 6 & 3.62 & 0.53 & & \\
$23-25$ & 149 & 3.65 & 0.63 & .217 & .929 \\
$26-28$ & 53 & 3.59 & 0.71 & & \\
$29-31$ & 17 & 3.65 & 0.67 & & \\
$32-34$ & 7 & 3.46 & 0.42 & & \\
\hline
\end{tabular}

Öğretmen adaylarının yaşam boyu öğrenme eğilimleri puanlarının yaşa göre dağılımına bakıldığında, ölçekten alınan puanların ortalamalarının $\bar{X}=3.46$ ile $\bar{X}=3.65$ arasında değişmektedir. Öğretmen adaylarının yaşam boyu öğrenme eğilimleri puanlarının yaşa göre 
dağılımında manidar bir farkın olup olmadığını ortaya koymak için yapılan tek yönlü varyans analizi sonucuna göre gruplar arası önemli bir farkın olmadığı görülmektedir $(F=, 217 ; \mathrm{p}>, 05)$.

Bölüm: Pedagojik formasyon eğitimi alan öğretmen adaylarının yaşam boyu öğrenme eğilimleri puanlarının mezun oldukları bölüm türüne göre farklılık gösterip göstermediği incelenmiş ve elde edilen sonuçlar Tablo 8'da verilmiştir.

Tablo 8

Bölüm Değişkenine Göre Yaşam Boyu Öğrenme Eğilimleri

\begin{tabular}{llllll}
\hline Bölüm & $\mathrm{n}$ & $\overline{\mathrm{X}}$ & $\mathrm{ss}$ & $\mathrm{F}$ & $\mathrm{p}$ \\
\hline Türk Dili ve Edebiyat1 & 58 & 3.60 & 0.50 & & \\
Biyoloji & 31 & 3.56 & 0.82 & 1.609 & .123 \\
Felsefe & 11 & 3.46 & 0.48 & & \\
Fizik & 15 & 3.55 & 0.51 & & \\
İngiliz Dili ve Edebiyat1 & 29 & 3.68 & 0.52 & & \\
Kimya & 26 & 4.00 & 0.79 & & \\
Sosyoloji & 5 & 3.54 & 1.10 & & \\
Tarih & 46 & 3.64 & 0.67 & & \\
Tak1 Teknolojileri ve Tasarımı & 11 & 3.34 & 0.30 & & \\
\hline
\end{tabular}

Öğretmen adaylarının yaşam boyu öğrenme eğilimleri puanlarının mezun oldukları bölüm türüne göre dağılımına bakıldığında, Felsefe ve Takı Teknolojileri ve Tasarımı bölümlerinden mezun olan öğretmen adaylarının yaşam boyu öğrenme eğilimlerinin ölçek ortanca değerinden (3.5) düşük ortalamaya sahip olduğu görülmüştür. Diğer bölümlerden mezun olan öğretmen adaylarının yaşam boyu öğrenme eğilimleri puan ortalamaları ise ölçek ortanca değerinden yüksektir. Ancak, öğretmen adaylarının yaşam boyu öğrenme eğilimleri puanlarının mezun oldukları bölüm türüne göre dağılımında anlamlı bir farkın olup olmadığını ortaya koymak için yapılan tek yönlü varyans analizi sonucuna göre gruplar arasında anlamlı bir farkın olmadığı görülmektedir $(\mathrm{F}=1,609 ; \mathrm{p}>, 05)$.

Yaşam Boyu Öğrenme Ĕgilimi İle Öğretmenlik Mesleğine Yönelik Tutum Arasındaki İlişki Pedagojik formasyon eğitimi alan öğretmen adaylarının hem yaşam boyu öğrenme eğilimleri hem de öğretmenlik mesleğine yönelik tutumlarında, cinsiyet ve yaş değişkenlerine göre anlamlı fark bulunmamıştır. Öğretmen adaylarının mezun oldukları bölüme göre öğretmenlik mesleğine yönelik tutumlarında fark görünürken, yaşam boyu öğrenme eğilimlerinde anlamlı bir fark görülmemiştir. Genel olarak değerlendirildiğinde, öğretmen adaylarının öğretmenlik mesleğine yönelik tutumlarının pozitif yönde olumlu ve yaşam boyu öğrenme eğilimlerinin ise yüksek olduğu söylenebilir.

Öğretmen adaylarının "yaşam boyu öğrenme eğilimleri” ile "öğretmenlik mesleğine yönelik tutumları" arasında anlamlı bir ilişki olup olmadığını belirlemek amacıyla korelasyon analizi yapılmıştır (Tablo 9).

Tablo 9

ÖMYT ile YBÖE arasındaki ilișki

\begin{tabular}{|c|c|c|c|c|c|c|}
\hline \multicolumn{7}{|c|}{ Model Özeti } \\
\hline \multicolumn{2}{|c|}{ Model } & $\mathrm{r}$ & $\mathrm{r}^{2}$ & & Düzenlenmiş $\mathrm{r}^{2}$ & Standart Hata \\
\hline \multicolumn{2}{|l|}{1} & $413^{\mathrm{a}}$ &, 170 & & 167 & 18,45784 \\
\hline \multicolumn{7}{|c|}{ ANOVA $^{\mathrm{a}}$} \\
\hline \multicolumn{2}{|l|}{ Model } & $\begin{array}{l}\text { Kareler } \\
\text { Toplamı }\end{array}$ & sd & $\begin{array}{l}\text { Ortalama } \\
\text { Karesi }\end{array}$ & $\mathrm{F}$ & Sig. \\
\hline \multirow[t]{2}{*}{1} & $\begin{array}{l}\text { Regression } \\
\text { Residual }\end{array}$ & $\begin{array}{l}16086,431 \\
78359,144\end{array}$ & $\begin{array}{l}1 \\
230\end{array}$ & $\begin{array}{l}16086,431 \\
340,692\end{array}$ & 47,217 &, $000^{\mathrm{a}}$ \\
\hline & Toplam & 94445,575 & 231 & & & \\
\hline
\end{tabular}


Tablo 9'daki analiz sonuçları incelendiğinde, pedagojik formasyon eğitimine katılan öğretmen adaylarının yaşam boyu öğrenme eğilimlerinin, öğretmenlik mesleğine yönelik tutumlarının anlamlı bir yordayıcısı olduğu söylenebilir $\left(r=0,413 ; r^{2}=0,170 ; F=47,217 ; p<0,01\right)$. Öğretmenlik mesleğine yönelik tutumuna ilişkin toplam varyansın \%17'sinin yaşam boyu öğrenme eğilimi ile açıklandığı söylenebilir.

\section{Öğretmen Adaylarının “Öğretmenlik Mesleği” Ve "Yaşam Boyu Öğrenme” Hakkındaki Görüşleri}

Pedagojik formasyon eğitimine katılan öğretmen adaylarına, öğretmenlik mesleği ve yaşam boyu öğrenme konusunda ne düşündüklerini ortaya koymak için iki açık uçlu soru ("Öğretmenlik sizin için ne ifade ediyor?" ve "Yaşam boyu ögrenme sizin için ne ifade ediyor?") sorulmuştur. Öğretmen adaylarına sorulan "Öğretmenlik sizin için ne ifade ediyor?" sorusuna 91 ögretmen adayı cevap vermiştir. Verilen cevaplar tema ve alt temalara ayrılarak Tablo 10'da oluşturulmuştur.

Tablo 10

“Öğretmenlik sizin için ne ifade ediyor?" sorusuna verilen cevaplar

\begin{tabular}{llll}
\hline Tema ve Alt Temalar & $\mathrm{f}$ & $\%$ & $\sum \%$ \\
\hline Öğretici Olarak Öğretmenlik & 31 & 100 & 34 \\
\hline Yeni nesillerin yetiştirilmesine katkıda bulunmak & 10 & 32 & \\
İnsanlara bir şeyler ögretmek & 8 & 26 & \\
Rehberlik etmek & 6 & 19 & \\
Ebeveynlik yapmak & 3 & 10 & \\
İnsanlara yardım etmek & 2 & 6 & \\
Aileyi tamamlamak & 2 & 6 & \\
\hline Kişisel Gelişim Olarak Ö̆ğretmenlik & 16 & 100 & 18 \\
\hline Yeni şeyler öğrenmek & 8 & 50 & \\
Öğretirken öğrenme firsatı yakalamak & 6 & 38 & \\
Illetişim becerilerini arttırmak & 2 & 13 & \\
\hline Meslek Olarak Öğretmenlik & 44 & 100 & 48 \\
\hline Sayginlık sağlayan bir meslek & 10 & 23 & \\
Mutluluk duyacağım bir meslek & 7 & 16 & \\
Hayatın anlamını bulacağım bir meslek & 7 & 16 & \\
Yapılması gereken kutsal bir meslek & 6 & 14 & \\
Sorumluluk gerektiren bir meslek & 4 & 9 & \\
Çok emek isteyen bir meslek & 3 & 7 & \\
Hayallerimdeki meslek & 3 & 7 & \\
Gurur duyduğum bir meslek & 2 & 5 & \\
Sadece bir meslek & 2 & 5 & \\
\hline Toplam & 91 & & 100 \\
\hline
\end{tabular}

Tablo 10'a bakıldığında, öğretmen adaylarının cevapları üç tema altında toplanmıştır. Bunlardan birincisi, öğretmen adaylarının \%34'ünün $(n=31)$ öğretmenliğin öğreticilik rolünü vurguladıkları "öğretici olarak öğretmenlik" temasıdır. "Öğretici olarak öğretmenlik" temasını oluşturan alt temalara bakıldığında ise 10 öğretmen adayı, öğretmenliği "yeni nesillerin yetiştirilmesine katkıda bulunmak" olarak tanımlarken, 8 öğretmen adayı ise öğretmenliği "insanlara bir şeyler öğretmek" şeklinde tanımlamışlardır. Ayrıca, öğretmenliği, 6 öğretmen adayı "rehberlik etmek", 3 öğretmen adayı, "ebeveynlik yapmak", 2 öğretmen adayı "insanlara yardım etmek" ve 2 öğretmen adayı da "aileyi tamamlamak" olarak tanımlamışlardır.

Diğer bir tema ise öğretmen adaylarının \%18'inin $(n=16)$ öğretmenliği kendilerini geliştirebilecekleri bir meslek olarak vurguladıkları "kişisel gelişim olarak öğretmenlik" 
temasıdır. Öğretmen adayları, öğretmenliği, öğretirken yeni şeyler öğrenebileceklerini $(n=8)$, öğretirken öğrenme fırsatı yakalayacaklarını $(n=6)$ ve öğretirken iletişim becerilerini arttırabileceklerini $(\mathrm{n}=2)$ düşündükleri bir firsat olarak görmektedirler.

Belirlenen son tema ise, soruya cevap veren öğretmen adaylarının neredeyse yarısının (\%44; n:44), öğretmenliği bir meslek olarak gördüklerini ifade ettikleri "meslek olarak öğretmenlik" temasıdır. Öğretmen adaylarının büyük çoğunluğu, öğretmenliği, saygınlık sağlayan $(\mathrm{n}=10)$, mutlu olacakları $(\mathrm{n}=7)$, hayatın anlamını bulacakları $(\mathrm{n}=7)$, kutsal $(\mathrm{n}=6)$, sorumluluk gerektiren $(n=4)$, çok emek isteyen $(n=3)$, hayalinin kurulduğu $(n=3)$, gurur duyulacak $(n=2)$ bir meslek olarak tanımlamışlardır. Fakat iki öğretmen adayı da öğretmenliğin sadece bir meslek olduğunu ifade ederek öğretmenliğe olumsuz baktıkları söylenebilir.

Öğretmen adaylarına sorulan "Yaşam boyu öğrenme sizin için ne ifade ediyor?" sorusuna 76 öğretmen adayı cevap vermiştir. Verilen cevaplar tema ve alt temalara ayrılarak Tablo 11'de oluşturulmuştur.

Tablo 11

"Yaşam boyu öğrenme sizin için ne ifade ediyor?" sorusuna verilen cevaplar

\begin{tabular}{llll}
\hline Tema Ve Alt Temalar & $\mathrm{f}$ & $\%$ & $\sum \%$ \\
\hline Öğrenme Aracı Olarak Yaşam Boyu Öğrenme & 25 & 100 & 33 \\
\hline Bilgi edinmek. & 14 & 56 & \\
Her yaşta öğrenebilmek. & 11 & 44 & \\
\hline Gelişimin Anahtarı Olarak Yaşam Boyu Öğrenme & 51 & 100 & 67 \\
\hline Kendini geliştirmek. & 28 & 55 & \\
Yaşama uyum sağlamak. & 23 & 45 & \\
\hline Toplam & 76 & & 100 \\
\hline
\end{tabular}

Tablo 11'e bakıldığında, öğretmen adaylarının cevapları iki tema altında toplanmıştır. Bunlardan birincisi, öğretmen adaylarının \%33'ünün $(n=25)$ yaşam boyu öğrenmenin bir öğrenme aracı olma özelliğini vurguladıkları "öğrenme aracı olarak yaşam boyu öğrenme" temasıdır. "öğrenme aracı olarak yaşam boyu öğrenme" temasını oluşturan alt temalara bakıldığında ise 14 öğretmen adayı, yaşam boyu öğrenmeyi "bilgi edinmek" olarak tanımlarken, 11 öğretmen aday1 ise yaşam boyu öğrenmeyi "her yaşta öğrenebilmek" şeklinde tanımlamışlardır.

Belirlenen ikinci tema ise, soruya cevap veren öğretmen adaylarının büyük çoğunluğunun (\%67; n:51), yaşam boyu öğrenmeyi gelişimin anahtarı olarak gördüklerini ifade ettikleri "gelişimin anahtarı olarak yaşam boyu öğrenme" temasıdır. Öğretmen adaylarının \%55' $(n=28)$ yaşam boyu öğrenmeyi, kendini geliştirmek olarak tanımlarken, $\% 45$ 'i $(n=23)$ yaşama uyum sağlamak olarak tanımlamışlardır.

\section{Tartışma ve Sonuç}

$\mathrm{Bu}$ çalışmada, pedagojik formasyon eğitimi alan öğretmen adaylarının öğretmenlik mesleğine yönelik tutumları ve yaşam boyu öğrenmeye ilişkin eğilimleri çeşitli değişkenlere göre incelenmiş ve öğretmenlik mesleğine yönelik tutumları ile yaşam boyu öğrenmeye ilişkin eğilimleri arasında herhangi bir ilişkisinin olup olmadığı incelenmiştir.

Formasyon eğitimi alan öğretmen adaylarının öğretmenlik mesleğine yönelik tutumlarında pozitif yönde olumlu bir eğilim olduğu bulunmuştur. Öğretmenlik mesleğine yönelik olumlu tutuma sahip olan öğretmenlerin, mesleklerini severek ve isteyerek yerine getirebilecekleri, yaptıkları işe gerekli özeni ve özveriyi gösterebilecekleri ve bunun sonucunda, sorumlu oldukları öğrencilerin eğitimine önemli katkılarda bulunabilecekleri söylenebilir. Alan yazın incelendiğinde, eğitim fakültesi kökenli öğretmen adaylarının öğretmenlik mesleğine yönelik tutumlarını inceleyen çalışmalar (Akpınar, Yıldız ve Ergin, 2006; Ayık ve Ataş, 2014; Başbay, Ünver ve Bümen, 2009; Bedel, 2008; Bulut, 2009; Çağlar, 2013; Doğan ve Çoban, 2009; Terzi ve Tezci, 2007), öğretmen adaylarının öğretmenlik mesleğine yönelik olumlu 
tutuma sahip olduklarını bulmuşlardır. Ek olarak, Arastaman (2013) ve Can (2010), yapmış oldukları çalışmalarda fen-edebiyat fakültesi öğrencilerinin öğretmenlik mesleğine yönelik olumlu tutuma sahip olduklarını saptamışlardır. Fen-edebiyat fakültesi öğrencilerinin, pedagojik formasyon eğitimini yeni almalarına rağmen, öğretmenlik mesleğine yönelik olumlu tutma sahip olmalarının sebeplerinden birisi, fen-edebiyat fakültesi öğrencilerinin iş bulma olasılıklarının kısıtlı olmasından dolayı öğretmenlik mesleğini bir zorunluluk olarak görmeleri olabilir. Bir diğer sebep de pedagojik formasyon eğitimi sonucunda alacakları öğretmenlik sertifikasıyla öğretmen olarak atanabilme şansı elde etmeleri olabilir. Ancak, alan yazında, öğretmen adaylarının öğretmenlik mesleğine yönelik olumsuz tutuma sahip olduğunu saptayan çalışmalar (Kahyaoğlu, Tan ve Kaya, 2013; Osunde ve Izevbigie, 2006) da vardır. Kahyaoğlu ve diğerleri (2013), öğretmen adaylarının öğretmenlik mesleğine yönelik olumsuz tutuma sahip olmalarının, ögretmen adaylarının mesleği tanımadan tercih etmelerinden veya öğretmenlik mesleğine yönelik isteksiz olmalarından kaynaklandığını ifade etmişlerdir.

Araştırmanın cinsiyet değişkenine ait bulguları incelendiğinde, pedagojik formasyon eğitimi alan öğretmen adaylarının öğretmenlik mesleğine yönelik tutumlarında anlamlı bir fark olmadığı saptanmıştır. Bu bulgu, öğretmenlik mesleğine yönelik tutumun cinsiyete göre farklılık göstermediğini ortaya koyan çalışmalar (Bulut ve Doğar, 2006; Can, 2010; Demirtaş ve diğerleri, 2011; Hacıömeroğlu ve Taşkın, 2010; Kılıç ve Bektaş, 2008; Semerci ve Semerci, 2004; Tanel, Şengören ve Tanel, 2007) tarafından desteklenmektedir. Ancak, alan yazında öğretmenlik mesleğine yönelik tutumda cinsiyete göre anlamlı bir farklılığın olduğu sonucuna ulaşan çalışmalar da vardır. Bu çalışmaların bazıları, erkek öğretmen adaylarının daha olumlu tutuma sahip olduklarını (Başçiftçi, Yanpınar ve Ergül, 2012; Özben, 2010) ortaya koyarken, bazı çalışmalar da (Akkaya, 2009; Akpınar ve diğerleri, 2006; Aksoy, 2010; Bozdoğan, Aydın ve Yıldırım, 2007; Gürbüz ve Kışoğlu, 2007; Pehlivan, 2008; Pektaş ve Kamer, 2011; Uğurlu ve Polat, 2011; Üstüner, Demirtaş ve Cömert, 2009; Yamaner ve Kartal, 2001), öğretmenlik mesleğine yönelik tutumun cinsiyete göre farklılık gösterdiğini ve kadın öğretmen adaylarının, erkek öğretmen adaylarına göre daha olumlu tutum sergiledikleri sonucuna ulaşmışlardır. Cinsiyet değişkenine ilişkin bu farklı bulgular, aslında öğretmenlik mesleğinin bir cinsiyetinin olmadığını, bireylerin bakış açısına göre değiştiği ile açıklanabilir.

Araştırmanın bölüm değişkenine ait bulguları incelendiğinde, pedagojik formasyon eğitimi alan öğretmen adaylarının öğretmenlik mesleğine yönelik tutumlarında anlamlı bir farkın olduğu görülmüştür. Üstüner ve diğerleri (2009), Bulut (2009), Aksoy (2010) ve Yaşar Ekici (2014) yapmış oldukları çalışmalarda, öğretmenlik mesleğine yönelik tutumun lisans programı değişkenine göre farklılaştığı saptamışlardır. Yaşar Ekici'ye (2014) göre, farklı sonuçların çıkması, ögretmen adaylarının mezun olacakları bölümü bilinçli ve isteyerek tercih edip etmemelerinden, lisans eğitimi sürecinde mezuniyet sonrası kariyer planlarının değişip değişmemesinden ve lisans eğitimi süresinde kaliteli eğitim alıp almamalarından kaynaklanabileceğini ifade etmiştir. Elde edilen bu sonucun aksine, alan yazında öğretmenlik mesleğine yönelik tutumun bölüm (lisans programı) değişkenine göre anlamlı bir farkın olmadığını gösteren çalışmalar (Çapri ve Çelikkaleli, 2008; Demirtaş ve diğerleri, 2011; Eraslan ve Çakıcı, 2011; Erdem ve diğerleri, 2005; Ocak ve Demirdelen, 2008; Şimşek, 2005) da vardır.

Öğretmen adaylarının yaşam boyu öğrenme eğilimlerine bakıldığında, yaşam boyu öğrenme eğilimlerinin yüksek olduğu söylenebilir. Sürekli yenilikleri takip etmek ve bilgi edinmek çağımızda toplumların gelişmesi ve kalkınmalarında en önemli değer haline gelmiştir. Bundan dolayı, toplumu oluşturan bireylerin yaşam boyu öğrenme eğilimlerinin yüksek olması ve yaşam boyu öğrenme becerilerine sahip olması büyük önem taşımaktadır. Öğretmenlerin toplumda lider olarak görülmeleri, özellikle onların yaşam boyu öğrenme becerilerine sahip olması gerektiği gerçeğini ortaya çıkarmaktadır. Bu araştırmada elde edilen sonuçlara göre, pedagojik formasyon eğitimi alan öğretmen adaylarının yüksek yaşam boyu öğrenme eğilimine sahip oldukları söylenebilir.

Pedagojik formasyon eğitimi alan öğretmen adaylarının cinsiyet değişkenlerine göre anlamlı bir fark olmadığı görülmüştür ve hem erkek öğretmen adaylarının hem de kadın öğretmen adaylarının yaşam boyu öğrenme eğilim ortalamaları ölçek ortanca değerinden yüksek 
olması da yaşam boyu öğrenmeye yönelik olumlu bir eğilim olduğu söylenebilir. Ayrıca, yaşam boyu öğrenme eğilimleri ortalamaları, erkek öğretmen adaylarının yaşam boyu öğrenme eğilimlerinin kadın öğretmen adaylarının eğilimlerine göre daha yüksek olduğu söylenebilir. Alan yazın incelendiğinde, bu araştırmanın bulguları, cinsiyet değişkeninin yaşam boyu öğrenme eğilimlerine bir etkisinin bulunmadığını gösteren araştırmaların (Oral ve Yazar, 2015; Şahin, Akbaşlı ve Yanpar Yelken, 2010; Yaman, 2014) bulgularıyla örtüşmektedir. Bu sonuçlardan farklı olarak, Demirel ve Akkoyunlu ( 2010), İzci ve Koç (2012), Gencel (2013), Karakuş (2013), Kılıç ve Tuncel (2014), Konokman ve Yelken (2014) yaptıkları araştırmalarda yaşam boyu ögrenme eğilimleri ile cinsiyet değişkenleri arasında kadınlar lehine anlamlı bir farklılık olduğunu ifade etmişlerdir.

Yaş değişkenlerine göre formasyon eğitimi alan öğretmen adaylarının yaşam boyu öğrenme eğilimlerinde bir fark bulunmamıştır. Kılıç (2014) ile Çam ve Üstün (2016) yapmış oldukları çalışmalarda da öğretmen adaylarının yaşam boyu eğilimlerinin yaşa göre farklılaşmadığını bulmuşlardır. 32-34 yaş grubunda bulunan formasyon eğitimi alan öğretmen adaylarının yaşam boyu eğilim ortalamalarında bakıldığında, diğer grupların ortalamalarından ve ölçek ortalamasından düşük olduğu söylenebilir. Ancak, bu yaş grubunda sadece yedi öğretmen adayının olmasından dolayı, Coşkun ve Demirel (2012) ve Çam ve Üstün'ün (2016) de belirttikleri gibi yaş ilerledikçe yaşam boyu öğrenme eğiliminin azaldığı yorumunu yapmak doğru olmayabilir.

Tüm bölümlerdeki formasyon eğitimi alan öğretmen adaylarının yaşam boyu öğrenme eğilimleri ölçeğinden bölüm olarak aldıkları aritmetik ortalamalara bakıldığında, yaşam boyu öğrenme eğilimlerinin orta düzeyde olduğu söylenebilir. Ancak, bölüm değişkenine göre formasyon eğitimi alan öğretmen adaylarının yaşam boyu öğrenme eğilimlerinde bir fark bulunmamıştır ve bölüm değişkeninin, yaşam boyu öğrenme eğilimlerini etkileyecek bir değişken olmadığı söylenebilir. Bu bulgu, Oral ve Yazar (2015) ve Çam ve Üstün (2016)'ün çalışmalarında elde ettikleri bulgularla örtüşmektedir. Araştırmadan elde edilen sonuçlardan farklı olarak, İzci ve Koç (2012) ve Gencel (2013)'ün yapmış oldukları çalışmalarda, öğretmen adaylarının yaşam boyu öğrenme eğilimlerinde öğrenim görülen bölüm açısından istatistiksel olarak anlamlı fark olduğunu belirtmişlerdir.

Öğretmen adaylarının "yaşam boyu öğrenme eğilimleri” ile "öğretmenlik mesleğine yönelik tutumları" arasında 0.01 düzeyde, doğru (pozitif) yönlü orta düzeyde bir ilişkinin olduğu ve ögretmenlik mesleğine yönelik tutumun toplam varyansının \%17'sinin yaşam boyu öğrenme eğilimi ile açıklandığı söylenebilir. Bir başka ifadeyle, öğretmen adaylarının öğretmenlik mesleğine yönelik tutumları yükseldikçe, yaşam boyu öğrenme eğilimleri de yükselecek, öğretmenlik mesleğine yönelik tutum azaldıkça da yaşam boyu öğrenme eğilimleri de azalacaktır denilebilir. Çünkü öğretmen olarak, öğrencilerini iyi yetiştirmeyi ve öğrencilerinin öğrenmesini kolaylaştırmayı amaçlayan bir öğretmen sürekli araştırma içinde olacak ve yeni yöntem ve teknikler araştırma ve kendi bilgisini sürekli güncel tutma ihtiyacı duyacaktır. Bunun sonucunda da araştıran, yeni bilgiler edinen yani yüksek yaşam boyu ögrenme eğilimine sahip öğretmen haline gelecektir. Bu araştırmadan elde edilen sonuç, Çam ve Üstün (2016)'ün yapmış oldukları çalışmayla da örtüşmektedir.

Ayrıca, öğretmen adaylarının açık uçlu sorulara verdikleri cevaplardan öğretmenliği nasıl gördükleri üç tema (öğretici, kişisel gelişim ve meslek) altında, yaşam boyu öğrenmeyi nasıl gördükleri de iki tema (öğrenme aracı ve gelişimin anahtarı) altında toplanmıştır. Temalar incelendiğinde, pedagojik formasyon eğitimi alan öğretmen adaylarının vermiş olduğu cevaplar, öğretmenlik mesleğine yönelik tutum ile yaşam boyu öğrenme eğilimi arasında olumlu bir ilişkinin olduğunu desteklemektedir. Öğretmen adayları hem yaşam boyu öğrenmeyi hem de öğretmenliği, kişisel gelişim ve gelişimin anahtarı olarak görmektedirler. Ayrıca, öğretmenliğin saygınlığını ve sorumluluğunu (Meslek) ve yeni nesillerin gelişimine katkıda bulunmak (Öğretici olma) özellikleri, öğretmen adaylarının yaşam boyu öğrenmeyi bir öğrenme arac1 olarak gördükleri söylenebilir.

Çalışmada elde edilen bulgular doğrultusunda öğretmen adaylarının yaşam boyu öğrenme eğilimlerinin yaş değişkenine göre farklılık gösterip göstermediğini ortaya koyacak 
çalışmalar yapılabilir. Ayrıca, pedagojik formasyon eğitimi aldıktan sonra ataması gerçekleştirilen öğretmenlerin, öğretmenlik mesleğine yönelik tutumları ve yaşam boyu öğrenme eğilimleri tekrar incelenebilir ve eğer bir farklılık varsa nedenleri araştırılabilir.

\section{Kaynaklar}

Akkaya, N. (2009). Öğretmen adaylarının öğretmenlik mesleğine yönelik tutumlarının bazı değişkenlere göre incelenmesi. Dokuz Eylül Üniversitesi Buca Eğitim Fakültesi Dergisi, 25, 35-42. Erişim adresi: http://acikerisim.deu.edu.tr/xmlui/bitstream/handle/ 12345/219/192.pdf

Akpınar, E, Yıldız, E. ve Ergin, Ö. (2006). Fen bilgisi öğretmen adaylarının öğretmenlik mesleğine yönelik tutumları. Dokuz Eylül Üniversitesi Buca Eğitim Fakültesi Dergisi, 19, 56-62. Erişim adresi: http://www.befjournal.com/index.php/dergi/article/download $/ 127 / 104$

Aksoy, M. E. (2010). Öğretmen adaylarının öğretmenlik mesleğine ilişkin tutumları. Sosyal Bilimler Araştırmaları Dergisi, 2, 197-212.

Arastaman, G. (2013). Eğitim ve fen edebiyat fakültesi öğrencilerinin öz-yeterlik inançları ve öğretmenlik mesleğine karşı tutumlarının incelenmesi. Ahi Evran Üniversitesi Kırşehir Eğitim Fakültesi Dergisi (KEFAD), 14(2), 205-217. Erişim adresi: http://dergipark.ulakbim.gov.tr /aeukefd/article/view/5000086823/0

Ayık, A. ve Ataş, Ö. (2014). Öğretmen adaylarının öğretmenlik mesleğine yönelik tutumları ile öğretme motivasyonları arasındaki ilişki. Eğitim Bilimleri Araştırmaları Dergisi (Journal of Educational Sciences Research), 4(1), 25-43. Doi: 10.12973/jesr.2014.41.2

Başbay, M., Ünver, G. ve Bümen, N. T. (2009). Ortaöğretim alan öğretmenliği tezsiz yüksek lisans öğrencilerinin öğretmenlik mesleğine yönelik tutumları: Boylamsal bir çalışma. Kuram ve Uygulamada Eğitim Yönetimi, 59, 345-366.

Başçiftçi, F., Yanpınar, O. ve Ergül, M. (2011). Öğretmen adaylarının öğretmenlik mesleğine yönelik tutumlarının incelenmesi: Selçuk Üniversitesi örneği. The International Educational Technology Conference "Ietc", İstanbul, Bildiriler (2) içinde (s. 18871891).

Bedel, E. F. (2008). Okulöncesi öğretmen adaylarının öğretmenlik mesleğine ilişkin tutumları ve bazı kişilik özellikleri arasındaki ilişkiler. Ĕ̈itimde Kuram ve Uygulama, 4(1), 3148.

Bozdoğan, A. E., Aydın, D. ve Yıldırım, K. (2007). Öğretmen adaylarının öğretmenlik mesleğine ilişsin tutumları. Ahi Evran Üniversitesi, Kırşehir Eğitim Fakültesi Dergisi (KEFAD), 8(2), 83-97.

Bulut, H. ve Doğar, Ç. (2006). Öğretmen adaylarının öğretmenlik mesleğine karşı tutumlarının incelenmesi. Erzincan Ĕ̈itim Fakültesi Dergisi, 8(2), 13-27.

Bulut, İ. (2009). Öğretmen adaylarının öğretmenlik mesleğine yönelik tutumlarının değerlendirilmesi. Ziya Gökalp Eğitim Fakültesi Dergisi, 14, 13-24.

Can, Ş. (2010). Tezsiz yüksek lisans öğrencilerinin öğretmenlik mesleğine yönelik tutumları. Muğla Üniversitesi Sosyal Bilimler Enstitüsü Dergisi, 24, 13-28.

Coşkun Diker, Y. ve Demirel, M. (2012). Üniversite öğrencilerinin yaşam boyu öğrenme eğilimleri. Hacettepe Üniversitesi Ĕgitim Fakültesi Dergisi, 42, 108-120.

Coşkun Diker, Y. (2009). Üniversite öğrencilerinin yaşam boyu öğrenme eğilimlerinin bazı değişkenler açısından incelenmesi (Yayımlanmamış doktora tezi). Hacettepe Üniversitesi Sosyal Bilimler Enstitüsü, Eğitim Bilimleri Bölümü, Eğitim Programları ve Öğretim Anabilim Dalı, Ankara. 
Çağlar, Ç. (2013). The relationship between the levels of alienation of the education faculty students and their attitudes towards the teaching profession. Educational Sciences: Theory ve Practice, 13(3), 1507-1513.

Çam, E. ve Üstün, A. (2016). Öğretmenlerin mesleki tutumları ile yaşam boyu öğrenme eğilimleri arasındaki ilişki. Hitit Üniversitesi Sosyal Bilimler Enstitüsü Dergisi, 9(1), 459-475. Doi: 10.17218/Husbed.58800

Çapri, B. ve Çelikkaleli, Ö. (2008). Öğretmen adaylarının öğretmenliğe ilişkin tutum ve mesleki yeterlik inançlarının cinsiyet, program ve fakültelerine göre incelenmesi. İnönü Üniversitesi Ë̆itim Fakültesi Dergisi, 9(15), 33-53.

Demirel, M. ve Akkoyunlu, B. (2010, Nisan). Öğretmen adaylarının yaşam boyu öğrenme eğilimleri ve bilgi okuryazarlığı öz-yeterlik algıları. (IETC) 10th. International Educational Technology Conference, 26-28 Nisan 2010, Istanbul, Türkiye, 10th. International Educational Technology Conference Proceedings Book, Volume 2, içinde (1126-1133). İstanbul: Boğaziçi Üniversitesi.

Demirtaş, H., Cömert, M. ve Özer, N. (2011). Öğretmen adaylarının öz-yeterlilik inançları ve öğretmenlik mesleğine ilişkin tutumları. Eğitim ve Bilim, 36(159), 96-111.

Doğan, T. ve Çoban, A. E. (2009). Eğitim fakültesi öğrencilerinin öğretmenlik mesleğine yönelik tutumları ile kaygı düzeyleri arasındaki ilişkinin incelenmesi. Eğitim ve Bilim, 34(153), 157-168.

Eraslan, L. ve Çakıc1, D. (2011). Pedagojik formasyon programı öğrencilerinin öğretmenlik mesleğine yönelik tutumları. Kastamonu Ĕ̆itim Dergisi, 19(2), 427-438.

Erdem, A. R., Gezer, K. ve Çokadar, H. (2005, Eylül). Ortaöğretim fen-matematik ve sosyal alanlar öğretmenliği tezsiz yüksek lisans öğrencilerinin öğretmenlik mesleğine ilişkin tutumları [Öz]. XIV. Ulusal Eğitim Bilimleri Kongresi, Denizli, 28-30 Eylül, Denizli, Kongre Kitabı I, içinde (s. 471-477).

Erkuş, A. (2011). Davranış bilimleri için bilimsel araştırma süreci. (3. Baskı). Ankara: Seçkin Yayıncilik.

Gencel, İ. E. (2013). Öğretmen adaylarının yaşam boyu öğrenme yeterliklerine yönelik algıları. Eğitim ve Bilim. 38(170), 237- 252.

Gürbüz, H.ve Kışoğlu, M. (2007). Tezsiz yüksek lisans programına devam eden fen-edebiyat ve eğitim fakültesi öğrencilerinin öğretmenlik mesleğine yönelik tutumları (Atatürk Üniversitesi örneği). Erzincan Eğitim Fakültesi Dergisi, 9(2), 71-83.

Hacıömeroğlu, G. ve Taşkın, Ç. Ş. (2010). Fen bilgisi öğretmenliği ve ortaöğretim fen ve matematik alanları eğitimi bölümü öğretmen adaylarının öğretmenlik mesleğine ilişkin tutumları. Ahi Evran Üniversitesi Eğitim Fakültesi Dergisi, 11(1), 77-90.

İzci, E. ve Koç, S. (2012). Öğretmen adaylarının yaşam boyu öğrenmeye ilişkin görüşlerinin değerlendirilmesi. Adlyaman Üniversitesi Sosyal Bilimler Enstitüsü Dergisi, 5(9), 101114.

Kahyaoğlu, M., Tan, Ç. ve Kaya, M. F. (2013). İlköğretim öğretmen adaylarının öğrenme stilleri ve öğretmenlik mesleğine yönelik tutumları. Mustafa Kemal Üniversitesi Sosyal Bilimler Dergisi, 10(21), 225-236.

Karakuş, C. (2013). Meslek yüksekokulu öğrencilerinin yaşam boyu öğrenme yeterlikleri. Journal of Research in Education and Teaching, 2(3), 26-35.

Karasar, N. (2010). Bilimsel araştırma yöntemi. Ankara: Nobel Yayıncılık.

Kılıç, Ç. (2014). Öğretmen adaylarının yaşam boyu öğrenmeye yönelik algıları. Eğitim ve Öğretim Araştırmaları Dergisi, 3(4), 79-87. Erişim adresi: http://www.jret.org/file upload/ks281142/file/08.kilic.pdf 
Kılıç, D. ve Bektaş, F. (2008). Sınıf öğretmeni adaylarının öğretmenlik mesleğine yönelik tutumlarının değerlendirilmesi. Atatürk Üniversitesi Kâzım Karabekir Eğitim Fakültesi Dergisi, 18, 15-25.

Kılıç, H. ve Tuncel, A. Z. (2014). İlköğretim branş öğretmenlerinin bireysel yenilikçilik düzeyleri ve yaşam boyu öğrenme eğilimleri. Uluslararası Eğitim Programlarl ve Öğretim Çalışmaları Dergisi, 4(7), 25-37.

Kurt, İ. (2000). Yetişkin eğitimi. Ankara: Nobel Yayın Dağıtım.

Milli Eğitim Bakanlığı (MEB). (2016). Öğretmenlik mesleği genel yeterlikleri. Erişim adresi: http://otmg.meb.gov.tr/yetgenel.html

Milli Eğitim Mevzuat (1973). Milli eğitim temel kanunu. Erişim adresi: http://mevzuat.meb.gov.tr/html/temkanun_0/temelkanun_0.html

Ocak, G. ve Demirdelen, C. (2008). Eğitim fakültesi öğrencileri ile tezsiz yüksek lisans öğrencilerinin öğretmenlik mesleğine yönelik tutumlarının karşılaştırılması. Erzincan Eğitim Fakültesi Dergisi, 10(2), 151-171.

Oktay, A. (1991). Öğretmenlik mesleği ve öğretmenin nitelikleri. Marmara Üniversitesi Atatürk Eğitim Fakültesi Ĕgitim Bilimleri Dergisi, 3, 187-193.

Oral, B. ve Yazar, T (2015). Öğretmen adaylarının yaşam boyu öğrenmeye ilişkin algılarının çeşitli değiş̧kenlere göre incelenmesi. Elektronik Sosyal Bilimler Dergisi, 14(52), (001011). Issn:1304-0278

Osunde, A. U. ve Izevbigie, T. I. (2006). An assessment of teachers' attitude towards teaching profession in midwestern Nigeria. Education, 126(3), 462-467.

Özben, Ş. (2010). Tezsiz yüksek lisans öğrencilerinin öğretmenlik mesleğine ilişkin tutumlarının incelenmesi. Dokuz Eylül Üniversitesi Buca Ĕ̈itim Fakültesi Dergisi, 1, $37-43$.

Pehlivan, K. B. (2008). Sınıf öğretmeni adaylarının sosyo-kültürel özellikleri ve öğretmenlik mesleğine yönelik tutumları üzerine bir çalışma. Mersin Üniversitesi Eğitim Fakültesi Dergisi, 4(2), 151-168.

Pektaş, M. ve Kamer, T. (2011). Fen bilgisi öğretmen adaylarının öğretmenlik mesleğine yönelik tutumları. Türk Eğitim Bilimleri Dergisi, 9(4), 892-850.

Semerci, N. ve Semerci, Ç. (2004). Türkiye'de öğretmenlik tutumları. Fırat Üniversitesi Sosyal Bilimler Dergisi, 14(1), 137-146.

Şahin, M., Akbaşl1, S. ve Yanpar Yelken, T. (2010). Key competences for lifelong learning: the case of prospective teachers. Educational Research And Review. 5(10), 545-556.

Şimşek, H. (2005). Ortaöğretim alan öğretmenliği tezsiz yüksek lisans programına devam eden öğrencilerin öğretmenlik mesleğine yönelik tutumları. Yüzüncü Yıl Üniversitesi Eğitim Fakültesi Dergisi, 2(1), 1-26.

Şişman, M. (2009). Öğretmen yeterlilikleri: modern bir söylem ve retorik. İnönü Üniversitesi Eğitim Fakültesi Dergisi, 10(3), 63-82.

Tanel, R., Şengören, K. S. ve Tanel, Z. (2007). Fizik öğretmen adaylarının öğretmenlik mesleğine ilişkin tutumlarının farklı değişkenler açısından incelenmesi. Pamukkale Üniversitesi Ë̆itim Fakültesi Dergisi, 2(22), 1-9.

Terzi, A. R. ve Tezci E. (2007) Necatibey Eğitim Fakültesi öğrencilerinin öğretmenlik mesleğine ilişkin tutumları. Kuram ve Uygulamada Eğitim Yönetimi, 52, 593-614.

Uğurlu, C. T. ve Polat, S. (2011). Sınıf öğretmenliği öğrencilerinin öğretmenlik mesleğine ilişkin tutumları. Cumhuriyet Üniversitesi Sosyal Bilimler Dergisi, 35(1), 68-74. 
Üstüner, M. (2006). Öğretmenlik mesleğine yönelik tutum ölçeğinin geçerlik ve güvenirlik çalışması. Kuram ve Uygulamada Eğitim Yönetimi, 45, 109-127.

Üstüner, M., Demirtas, H. ve Cömert, M. (2009). The attitudes of prospective teachers towards the profession of teaching (the case of Inonu, faculty of education). Egitim ve Bilim Dergisi, 34(151), 140-155.

Yaman, F. (2014). Öğretmenlerin yaşam boyu öğrenme eğilimlerinin incelenmesi (Diyarbakır ili örneği) (Yayımlanmamış yüksek lisans tezi). Dicle Üniversitesi Eğitim Bilimleri Enstitüsü, Diyarbakır.

Yamaner, F. ve Kartal, A. (2001). İnönü Üniversitesi Eğitim Fakültesi Beden Eğitimi ve Spor Bölümü'nde okuyan öğrencilerin öğretmenlik mesleğine yönelik tutumları. Atatürk Üniversitesi, Besyo Beden Ĕgitimi ve Spor Bilimleri Dergisi, 1(4), 121-132.

Yaşar Ekici, F. (2014). Öğretmen adaylarının öğretmenlik mesleğine yönelik tutumlarının çeşitli değişkenler açısından incelenmesi (İstanbul Sabahattin Zaim Üniversitesi örneği). Uluslararası Sosyal Araştırmalar Dergisi, 7(35), 658-665.

Yavuz Konokman, G. ve Yanpar Yelken, T. (2014). Eğitim fakültesi öğretim elemanlarının yaşam boyu öğrenme yeterliklerine ilişkin algıları. Hacettepe Üniversitesi Ë̆itim Fakültesi Dergisi, 29(2), 267-281.

Yüksek Öğretim Kurulu (YÖK) (2014). Pedagojik formasyon eğitimi sertifika programına ilişskin usul ve esaslar. Erişim adresi: http://www.yok.gov.tr/web/guest/icerik//journal_content/56_instance_rehf8bisfyrx/10279/7052802

\section{Extended Abstract}

\section{Introduction}

Curriculum, administrators, educationists, education technologies, physical facilities, financial sources, students and teachers are the parts which constitute the education systems and the teachers, the implementers of the curriculum, are important ones. For this reason, in order for today's teachers to be able to work self-sacrificingly, it is mandatory that they have positive attitude towards teaching profession and lifelong learning skills by means of which they can follow up the current developments, adopt to changes, and improve themselves continuously, and thus reflect these changes to class. The aim of the study was to shed light on the attitudes towards teaching profession and the lifelong learning tendencies of the teacher candidates attending to pedagogical formation certificate program according to various variables and highlight whether there was a meaningful relationship between the attitudes towards teaching profession and the lifelong learning tendencies. The sub-problems were given below:

1) Is there any difference in the attitudes towards teaching profession according to gender, age and department variables?

2) Is there any difference in the lifelong learning tendency of the teacher candidates according to gender, age and department variables?

3) Is there any meaningful relationship between the attitudes towards teaching profession and the lifelong learning tendencies?

4) What do the teacher candidates think about "teaching profession" and "lifelong learning"?

\section{Method}

232 teacher candidates participated in the study. \%62,1 $(\mathrm{n}=144)$ of the teachers candidates were female; \%37,9 ( $\mathrm{n}=88)$, male. The ages of the teacher candidates ranged from 20 to 34: \%2,6 $(\mathrm{n}=6)$ between 20 and 22; \%64,2 ( $\mathrm{n}=149)$, between 23 and 25; \%22,8 $(\mathrm{n}=53)$, between 26 and 28; \% 7,3 ( $\mathrm{n}=17)$, between 29 and 31 and $\% 3(\mathrm{n}=7)$; between 32 and 34. Besides, \%95,3 ( $\mathrm{n}=221)$ 
of the teacher candidates participated in the study were graduates of faculty of science and letters and \%4,7 $(\mathrm{n}=11)$ were Jewelry Technology and Design graduates.

Personal information sheet, "Attitude Scale of Teaching Profession (ASTP)", "Lifelong Learning Tendency Scale (LLTS)" and two open ended questions were used to collect the data. ASTP developed by Üstüner (2006) has 24 positive and 10 negative items and designed as 5Likert type scale (5- Totally agree to 1-Totally Disagree). The item-test correlation of the scale ranged from 0,42 to 0,74 and the scale validity was found to be 0,89 ; internal validity (Cronbach Alfa); 0,93 (Üstüner, 2006). The reliability of the scale in this study was found to be 0,89 . LLTS developed by Coşkun Diker (2009) has 27 items. All the items are positive and the scale has four sub-scales: motivation (6 items), Perseverance (6 items), Lack of Regulating Learning (6 items) and Lack of Curiosity (9 items). Internal validity (Cronbach Alfa) of the scale was found to be 0,89 (Coşkun Diker, 2009). The reliability of the scale in this study was found to be 0,85 . Besides these scales, two open-ended questions, aimed to shed light on what they are thinking about teaching profession and lifelong learning, were added to the scale. The first one was "What does "teaching" mean to you?" and the other was "What does "lifelong learning" mean to you?".

265 teacher candidates attending to pedagogical formation certificate program in 20132014 academic year were participated in the study. Because of the missing data such as handing in the data collection tools incomplete or unfilled, the data obtained from 33 teacher candidates were omitted and the data obtained from 232 teacher candidates were used in the analysis. The data obtained from the scales were analyzed in terms of gender, age and department variables. For the gender variable, independent samples t-test; for the other variables, one-way ANOVA were used to analyze the data. In order to underline whether there was a meaningful relationship between ASTP and LLTS, Pearson coefficient of correlation was calculated. Content analysis was used to analyze the qualitative data collected from the open-ended questions. The researchers analyzed the qualitative data independently and later the findings were compared. Miles Huberman Reliability analysis was administered and the reliability of the analysis for the opinions of the teacher candidates related to teaching profession was found to be $85 / 90=0,94$ and for those related to lifelong learning; 78/81=0,96.

\section{Results and Discussion}

It can be said that the teacher candidates attending to pedagogical formation certificate program had positive attitudes towards the teaching profession. When the data about gender and age variables were analyzed, it was found that there were no significant differences in the attitudes of the teacher candidates attending to pedagogical formation certificate program towards teaching profession according to not only gender but also age variables. It was found that there was a difference according to the departments they were graduated from $(F=7,939 ; p>0,05)$. This difference was between Turkish Language and Literature Department and Biology $(\mathrm{p}=, 000<, 05)$, Philosophy $(\mathrm{p}=, 000<, 05)$, Physics $(\mathrm{p}=007<, 05)$, English Language and Literature $(\mathrm{p}=, 000<, 05)$, Chemistry $(\mathrm{p}=, 000<, 05)$, Sociology $(\mathrm{p}=, 000<, 05)$, Jewelry Technology and Design $(\mathrm{p}=, 000<, 05)$, and History $(\mathrm{p}=, 000<, 05)$ departments.

When the lifelong learning tendencies of the teacher candidates were considered, it can be said that their lifelong learning tendencies were high $\left(X=128,59>X_{\text {scalemean }}=94,5\right)$. No differences in the lifelong learning tendencies of the teacher candidates attending to pedagogical formation certificate program according to gender, age and department variables. While the lifelong learning tendencies of the teacher candidates were quite high according to gender variable, their lifelong learning tendencies seemed to be at medium level when the department variable was considered.

It can also be underlined that there was a positive medium-level relationship between the attitudes towards teaching profession and the lifelong learning tendencies of the teacher candidates attending to pedagogical formation certificate program at 0,01 significance level $\left(r_{(232)}=0,413, p<0,01\right)$. Besides, the responses to the open-ended questions of the teacher 
candidates as to how they saw the teaching profession were grouped under three themes and those as to how they perceived lifelong learning under two themes.

Teachers having positive attitude towards teaching profession can be said to carry out their profession willingly and fondly and to show necessary attention and devotion to what they do, as a result of which, they can contribute to the education of the students they are responsible for. Likewise, a teacher, who wish to educate their students well and to ease their learning, will be in constant research and in need of searching for new methods and techniques and keep their knowledge up-to-date. Thus, they will become the ones who have high lifelong learning tendencies. 